\title{
SABBATARIAN LITERATURE FROM THE 17TH CENTURY AND THE CONTRIBUTION OF SIMON PECHI
}

\author{
IOAN-GHEORGHE ROTARU \\ „Timotheus” Brethren Theological Institute of Bucharest \\ \& ,Aurel Vlaicu” University of Arad, Romania
}

\begin{abstract}
Rezumat. Atât sabatarianismul cât şi creaţia poetică a acestuia din perioada aceasta s-a aflat sub influenţa lui Simon Péchi. Majoritatea creaţiilor poetice a sabatarienilor au curs din peniţa lui Péchi, care a trasat şi direcţia de viitor în privinţa acestui gen de creație. Preocuparea sabatarienilor a fost pentru traducerea imnurilor religioase evreieşti, precum şi pentru prelucrarea acestora. Iar literatura care a luat fiinţă, şi care până acum este o literatură poetică aproape necunoscută, care nu este nici chiar foarte vastă şi care a ajuns la noi cu multe lipsuri, intr-o anumită privinţă este inegalabilă şi în mod deosebit este plină cu învăţături în ceea ce priveşte acea schimbare radicală, prin care a trecut sabatarianismul din momentul în care Simon Péchi a ajuns să fie în fruntea lui.
\end{abstract}

Cuvinte-cheie: Péchi Simon, literatura sabatariană, creația poetică, scriitor, ebraist.

Abstract. Both Sabbatarianism and its poetic creation from this period were under the influence of Simon Péchi. Most of the poetic creations of the Sabbatarians came from the pen of Péchi, who also outlined the future direction regarding this kind of creation. The concern of the Sabbatarians was for the translation of Jewish religious hymns, as well as for their processing. And the literature which emerged, and which until now is an almost unknown poetic literature, which is not even very wide and which has come to us with many shortcomings, in one respect is unmatched and especially full of teachings as regarding that radical change, through which Sabbatarianism has passed from the moment Simon Péchi has reached to lead it.

Keywords: Péchi Simon, Sabbatarian Literature, Poetic Creation, Writer, Hebraist.

\section{Introduction}

The Sabbatarians of Transylvania expressed, in the XVI-XVII centuries, specifically their dogmatic belief in the works, poems and songs created or translated. Even in the works that were translated, the Sabbatarians removed those parts that were contrary to their religious conception and introduced any element that was useful to their creed.

Here are those smaller or larger writings in prose, which establish the confession of faith of the Sabbatarians, in which some articles of faith are 
explained, which they argue and prove to be true. The literature also contains prayers for. the most important and frequent events in their religious life.

At the beginning, the Sabbatharian literature was written in the form of prose, and the processing in the poetic form of the Sabbath creed and of the specific prayers was done after the mentioned period. One thing is certain, namely that in Sabbatarianism poetry follows in the footsteps of prose literature, although in part it is possible that it arose even with prose. This literature, which is entirely written in Hungarian, came into being and developed very early, at the same time and in parallel with Sabbatarianism. Much of this literature, in all probability, dates from the latter part of the sixteenth century.

The most important contribution regarding the literature of the Sabbatarians was made by Simon Pechi, former chief chancellor of the prince of Transylvania, Gabriel Bethlen. Simon Pechi was a man of extraordinary erudition. From him remained the liturgy of the Sabbatarians and their entire religious literature. He laid the foundations and gave the form by which, despite all the vicissitudes, Sabbatarianism survived over four centuries (1570-1980).

The literary activity of Simon Péchi became a surrogate for him, especially after the fall from the high position of chancellor of Transylvania, because he could not find anymore his place in the political and social life. He filled this gap with his literary activity. For him, the Sabbatarian religion was not only a concern of the soul, but also an occupation of the mind by which he tried to fill the gap produced by his disappearance from social and political life, and his ideology was really a whole philosophy, strong and complex nourishment for the mind.

The Sabbatarian literature from the period of Simon Péchi is almost the only way we can know the Sabbatarian religion (Szávai, 2008, p. 219. 243-246) regarding its leaders, the evolution of this religious movement, the sacrifices and risks they were exposed to because of their religion.

\section{Péchi Simon and the Sabbatarian poetic creation}

Both Sabbatarianism and its poetic creation from this period were under the influence of Simon Péchi. Most of the poetic creations of the Sabbatarians came from the pen of Péchi, who also outlined the future direction regarding this kind of creation. The concern of the Sabbatarians was for the translation of Jewish religious hymns, as well as for their processing. And the literature which emerged, and which until now is an almost unknown poetic literature, which is not even very wide and which has come to us with many shortcomings, in one respect is unmatched and especially full of teachings as regarding that radical change, through which Sabbatarianism has passed from the moment Simon Péchi has reached to lead it.

I saw above that Simon Péchi, especially in the prayers for the holidays, took from the Sephardi Jewish liturgy religious songs, which he also translated. Here belong those songs, of which in the attached explanations, 
Péchi states that: "this song is said here". These songs, accompanied by explanations, which are included in every manuscript of the prayer book, give the original form of the Sabbattarian Prayer Book of Péchi. Their number is not large, but in total there are six such songs. However, in several places, Péchi emphasizes the fact that, although he has left out many other beautiful prayers, he promises that he will translate them later. This promise has also been fulfilled by him. Thus from the Sefard Machzor, as well as from Selichot, he chosed other songs, which he translated and collected in verses. So far, 16 such songs have been found. That they come from Péchi's pen does not bear any doubt, because they harmonize perfectly in all respects with those songs in the Sabbattarian Prayer Book of Péchi that I mentioned above. Their common sign of recognition is the fact that they have four-line stanzas, and each end of the line ends with the same rhyme. We refer to the songs written by Simon Péchi in Hungarian. In the Romanian translation, they no longer have the same rhyme. The beginning letters of the lyrics do not highlight anywhere the author's name, except for one (Kohn, 1889, p.251, note 1), no other reference is shown anywhere else. Simon Péchi, who had to take care of their translation, rhyme and faithful rendering of the Hebrew text, no longer made his work more difficult with such things, work, which was already quite difficult (Kohn, 1889, p.251, note 2).

To the fact that Péchi Simon is the author alludes also that circumstance according to which the Jewish liturgy, especially the Machzor, in the Sabbatean environment of that time and probably also in the environment before and even after, was not known, and was not understood by no one to such an extent as to translate from it the poetic parts, which are very difficult to understand even by the very experienced Hebraist. Here belong 7 more songs, which are not translations of Jewish religious poetic creations, but contain from them, namely, from halacha and haggada, more exactly from the ritual and ethical part of the Jewish tradition. Thus to Simon Péchi, from this period, we attribute 29 poems that became chants, of which 6 were collected in his Prayer Book, as the 16 mentioned above, so together 22, are the translation of Jewish liturgical songs, and the others 7 songs are the free processing of those fragments that were taken from the Jewish tradition (Kohn, 1889, p.251, note 3 ). In addition to these, we still have 14 Sabbath hymns, which are also from this period. They allude only to the Holy Scripture, from which also translate, but do not know the liturgy and the Jewish tradition, and they allude very little to the circumstances of that time, especially to the situation of Sabbatarianism at that time, which Simon Péchi, where he translated and processed the Jewish liturgy, he could not make it without being visible. This denotes the fact that there were other authors besides Péchi, although it is possible that some of them were also from Péchi's pen. From the 14 hymns, more precisely from the letters at the beginning of the lyrics, only at 7 chants, we can read the author's name. The hymn with a general content (with no. 40) is the creation of Sinka György; a song for the Sabbath (with no. 42, and 35) are the creations 
of Tolnai István respectively of Bökényi János. Two hymns for the New Year (with no. 37 and 39) were written by Magyar Péter; one was written for the feast of humility (with no. 41) by Gerghli; the poetic processing of a psalm (with no. 33) indicates the name of Sándor János. Of the ones mentioned above, with Bökényi János we have already met in the Old Book of Sabbathic hymns. Tolnai István in 1615 copied some Sabbatarian books in the locality Kis-Solymos (Soimoșu Mic), and in 1632 he printed a document addressed to The Faculty of Wittenberg, from which it can be concluded, that probably, he studied there (Kohn, 1889, p.252, note 1-3).

The mysterious Gerghli is probably identical with Szegedi Gergely, from which we have several translations of Psalms in the Book of Unitarian Hymns, which was published around 1600, and Magyari Péter is identical with Mederi Péter, one of Péchi's countrymen, used to be called ,the poet with the crown." The latter one, starting from the time of the Dej Process, was a teacher, and in 1640 he was appointed titular at the main desk in Brașov. Probably because of this position he held, he was more cautious in his poems, where he only mentioned his name through initials, but he did not have the courage to make his name clear. His Sabbatarian position is also reinforced by the fact that he named his son Asarel, and his daughter Asnath, names that are unusual for the culture of that time, Jewish names, respectively names taken from the Old Testament. We don't know anything about Sinka György and Sándor János until now (Kohn, 1889, p.252, note 4, p. 253, note 1).

These chants circulated in the hands of the Sabbatarians; and the most zealous of them noted them down in their hymn books, or wrote them on the remaining blank chants in their prayer book. Later those who copied these prayer books took over some chants in the actual text of the prayer book, written in different places, where according to that person's opinion was more appropriate to be intercalated. From here comes the fact that those chants of Péchi that he did not wrote for the Sabbatarian Prayer Book, as well as the religious songs of his compatriots, are found in certain Prayer Books of Péchi, especially in the copies that appeared much later. They are regularly found in The New Book of Sabbatarian Hymns from the following period and especially in the various manuscripts found in different places.

From the copies of the New Book of Hymns, of which the oldest one that came to us is from 1720 , we easily recognize those chants, which came into being during this period. The New Hymn Book contains a few pieces that arrived there from Bogathi's translation of Psalms, or from the Unitarian Hymn Book of Francis David's time (Kohn, 1889, p. 254, note 2). However, beyond this fact, we can easily distinguish between these chats and the songs of Péchi and of his countrymen. For the former ones, in part, the Sabbatarian Prayer Book of Péchi is made known, and on the other hand they are betrayed by the distinctive signs mentioned above, and of the latter ones, we can certainly remember that they come from the period about which we discuss here (1621-1638). They cannot be, in any case older, because in The Old Book 
Of Sabbatarian Hymns they are not found, but they could not be born neither later, because from the linguistic point of view, from the point of view of creation and rhyme it is in harmony with all other Sabbatarian songs of that period. Also, the authors of the lyrics, whose name derives from the letters at the ends of the lyrics, as we know them, lived during this period. On the other hand, after this period (1621-1638) the Sabbatarianism set off as far as creation is concerned, protecting only its poetic creation from before, modifying the old one in some parts, but did not created anything new. After 1638, nothing is created anymore, but are preserved all that Simon Péchi and his collaborators or countrymen wrote, along with the older writings, written before Péchi's writing period. In this period, after 1638, there are no new creations, but there are various works, which seem to have lost their originality and which, both in terms of extension and content, show a real negligence.

The Sabbatarianism in its glory period (1621-1638), rarely makes controversy in its songs and does not use every occasion to prove its true identity and character, or to gain new followers, things that happened in Sabbatarianism after 1638. Prior to 1638, Sabbatarianism was considered a definitive confession, which dealt only with itself, and which developed as Judaism tried to take more and more elements, which it harmonized with its own dogmatic needs. In the Hungarian literature there is nothing compared with this creation activity from the Jewish literature. There is something similar in German; but there the works are of more recent origin, and come exclusively from the pen of some Jews. The translation and poetic processing of the Jewish liturgical songs, to a large extent, was done for the first time by Simon Péchi, who placed the synagogical poetic creation, for the first time on the land of Transylvania, among the Szekler sabbatarians (Newman, 1966, p. 103-106, 113-115; Kohn, 1889, p. 254-255).

\section{Péchi Simon, writer and Hebraist}

The works of Péchi, which have been listed before, except for a small part of the political correspondence carried out abroad, are all written in Hungarian. And the Hungarian language used by Péchi is full of teachings regarding the literature and language of the Hungarian population of his period. Péchi reveals us some words, which are outdated today, but which were in circulation at his time. Some words he uses today have a different meaning. Simon Péchi uses in his works many regionalisms from Transylvania (Kohn, 1889, 286; Kohn,1888, p. 567-573).

Simon Péchi was a master of the pen. From his pen came out personal and official letters, messages for national assemblies (Diets), proposals for laws, instructions for foreign ambassadors and for other state dignitaries, orders for the army, memoirs for the political field, hymns and religious prayers. Péchi translated and respectively explained things from the Holy Scripture or from the books taken from later Jewish literature (Dukes, 1844, p. 67-84; Newman, 1966, p. 103-115). 
During the most agitated period from his first Chancellery, while he was also dealing with certain negotiations, Simon Péchi wrote The teachings taken from the Holy Fathers. After at the end of 1624 he was released from prison, until 1638 when he returns to prison, so within 14 years, Péchi translated and explained the Psalms, wrote his book of prayers and rituals and besides 29 religious poems, also bear the title of author for eight other works smaller or larger. In addition, he continued to write various stories for several trials, in order to re-enter into the possession of some confiscated goods. He wrote in detail about the administration of his estate. His way of writing is clear, energetic and obviously presents his ideas. However, he uses many words. He likes to explain things in two three similar words. Simon Péchi's way of writing is characterized by originality, in which the taste of his era sees a poetic finesse and beauty, especially in his translations, which are highlighted as being valuable. Simon Péchi does not support, or more correctly, does not want to reproduce the compressed and short form of the Hebrew texts. For example, at the beginning of Psalm 43 in this verse, „How a deer wants (as it cries thirsty) a fountain of water," the words written in bold italics are the addition of Péchi and similarly he proceeded with other texts. For example, the following thesis taken from the work Selected pearls: „By truth everything remains at its height, through lies it is damaged." (XXXV. 2), at Péchi the text is translated as follows: „By the truth he builds and strengthens all things; and the lie overturns, damages, destroys everything." Only the five books of Moses are translated by him as far as possible word by word, that is, with fidelity, because are regard as the Word of God, whose modification is considered to be a $\sin$ (Kohn, 1889, p. 286-288; Koltai, 2011).

On the other hand, it was truly magnificent, his ability to know the rabbinic literature. For the Jewish notions, for which he did not find a correspondent in Hungarian, he resorted to the creation, on a Jewish background, of new words in Hungarian. Simon Péchi is not confined to faithfully rendering Hebrew texts, but almost everywhere intercalates explanations, smaller or larger, for the understanding of his followers, and at other times eliminates whole parts, which according to him, contain theological discussions, which would be difficult to understand for the Szekler Sabbatarians. Simon Péchi does not adopt those parts of works that do not harmonize with the situation and creed of the Sabbatarians, or which recommend religious practices, which for them are unacceptable, or even impracticable. On the other hand, he completes the Hebrew original with explanations that discuss Jewish dogmas or religious practices. In many places Péchi rather processes than translates the Hebrew texts (Cohen, 1982, p. 45; Geiger, 1870, p. 68; Guttmann, 1950, p. 181193; Lővy, 1907, p. 286-289; Waxman, 1938, p. 81-82; Katona, 1976, p. 15; Klaniczay, 1961, p. 313-315; Klaniczay, 1973, p. 254; Kohn, p. 288, see also notes 1-4). 


\section{Conclusions}

At that time it was not easy to find a person who translated a so diverse work, respectively to process these works, as Simon Péchi did, and among these works there were some of whose translations other than Péchi`s no one has tried before. Mille de-abot of Chajun Jozsef, Szemag of Mosesben Jacob, the work of Izrael ben-Jozsef, Alnakva and Hanhaga of Aser ben-Jechiel, have not been translated into other forms today, except in the Hungarian translation of Péchi (Kohn, 1889, p. 289; Schurer, 1891, vol., I, p. 124; vol., II, p. 353, vol., III, p. 30; Kohut, 1885). Simon Péchi has translated 5000 pages of specialized literature (Dán, 1987, p. 311). And so we can certainly say that Simon Péchi, not only for the period in which he lived, but also for other times, occupies a place of honor among the nonJews Hebraists. About him, the rabbi of Budapest, Dr. Kohn Sámuel wrote that: „Péchi Simon regarding the well-known knowledge of the Hebrew language and literature certainly ranks first among the contemporary Hebraists of his time and occupies a prominent place among the Hebraists of all times" (Kohn, 1889, p. 289; Dán, 1987, p.207).

\section{Note:}

The paper Sabbatarian Literature from the 17th Century and the Contribution of Simon Pechi represents a variant in English, extracted from the author's work, published in Romanian, respectively:

ROTARU, Ioan-Gheorghe. Sabatarienii în contextul vieții transilvane (sec. XVI-XX). Doctrină, cult, organizare. Mănăstirile sabatariene. Ediţia a II-a revăzută şi adăugită, Vol. III., Cluj-Napoca, Editura Risoprint, 2019, p. 71-152, having a certain connection with other studies published on this topic by the author, respectiROTARU, Ioan-Gheorghe. Literatura primei perioade a sabatarianismului. In: Studia Universitatis Babeş-Bolyai, Theologia Orthodoxa. 2008, LIII, nr. 2, Cluj-Napoca, Presa Universitară Clujeană, p. 85-93.

ROTARU, Ioan-Gheorghe. Simon Péchi şi literatura sabatariană scrisă în proză. In: Studia Universitatis Babeş-Bolyai, Theologia Orthodoxa. 2010, LV, nr. 1, Cluj-Napoca, Presa Universitară Clujeană, p. 153-165.

\section{Referințe bibliografice:}

1. ABELSON, J. The Immanence of God in Rabbinical Literature. London, Macmillan, 1912.

2. DÁN, Róbert. Az erdélyi szombatosok és Péchi Simon. Budapest, Akadémiai Kiadó, 1987.

3. DUKES, Leopold. Rabbinische Blumenlese. Leipzig, Verlag, Hahn'sche Verlagsbuchh, 1844.

4. GEIGER, Abraham. Judaism and its History. New York, Bloch Pub., 1911.

5. GEIGER, Ludwig. Das Studium der Hebräischen Sprache in Deutschland. Breslau, Schletter sche Buchhandlung, 1870.

6. GOLDIN, Judah. The Living Talmud: The Wisdom of the Fathers. New York, Limited Editions Club, 1960. 
7. GUTTMANN, J.A. Tractate Aboth: its place in Rabbinic literature. In: Jewish Quarterly Review. 1950, XLI, p. 181-193.

8. KATONA, Imre. A hában kerámia Magyarországon. Budapest, Képzőművészeti Alap Kiadóvállalata, 1976.

9. KLANICZAY, Tibor. A múlt nagy korszakai. Budapest, Szépirodalmi Könyvkiadó, 1973.

10. KLANICZAY, Tibor. Reneszánsz és barokk. Budapest, Szépirodalmi Könyvkiadó, 1961.

11. KOHN, Sámuel. A szombatosok. Történetük, dogmatikájuk és irodalmuk. Budapest, Athenaeum Kiadó, 1889.

12. KOHN, Sámuel. A zsidók története Magyarországon. A legrégibb időktöl a mohácsi vészig. Budapest, Athenaeum Kiadó, 1884.

13. KOHN, Sámuel. A Zsidók Története Magyarországon. First part of a history of the Jews in Hungary. Budapest, 1884.

14. KOHN, Sámuel. Egy kiadatlan irodalom fől nem használt magyar nyelvkincsei. In: Magyar Nyelvör. 1888, XVII, p. 567-573.

15. KOHUT, Alexander. The Ethics of the Fathers. New York, Publication Office of ,the American Hebrew”, 1885.

16. KOLTAI, Kornélia. Péchi Simon kiadatlan Biblia-forditása (1634). Budapest, (M.T.A.), Judaisztikai Kutatóközpont, 2011.

17. LŐVY, Ferencz. Egy lap Péchi Simon Qohelet-forditásából. In: Magyar Zsidó Szemle. 1907, XXV, p. 286-289.

18. NEWMAN, Louis Israel. Jewish Influence on Christian Reform Movements. $2^{\text {nd }}$ ed., New York, 1966.

19. ROTARU, Ioan-Gheorghe. Literatura primei perioade a sabatarianismului. In: Studia Universitatis Babeş-Bolyai, Theologia Orthodoxa. 2008, LIII, nr. 2, Cluj-Napoca, Presa Universitară Clujeană, p. 85-93.

20. ROTARU, Ioan-Gheorghe. Sabatarienii în contextul vieții transilvane (sec. XVI-XX). Doctrină, cult, organizare. Mănăstirile sabatariene. Ediția a II-a revăzută şi adăugită, Vol. III., Cluj-Napoca, Editura Risoprint, 2019.

21. ROTARU, Ioan-Gheorghe. Simon Péchi şi literatura sabatariană scrisă în proză. In: Studia Universitatis Babeş-Bolyai, Theologia Orthodoxa. 2010, LV, nr. 1, ClujNapoca, Presa Universitară Clujeană, p. 153-165.

22. SCHÜRER, Emil. A History of the Jewish People in the Time of Jesus Christ. vol., I, II, III, New York, Charles Scribner's Sons, 1891.

23. SZÁVAI, Géza. Ierusalimul Secuiesc. Budapest, PONT Kiadó, 2008.

24. SZÁVAI, Géza. Székely Jeruzsálem. Budapest, PONT Kiadó, 2001.

25. TAYLOR, Charles. Sayings of the Jewish Father. 2 nd.ed., New York, Ktav, 1969.

26. WAXMAN, Meyer. A History of Jewish Literature. vol. I, New York, Bloch publishing co., 1938. 